DOI https://doi.org/10.30525/978-9934-26-114-5-74

\title{
ОСОБЛИВОСТІ РОЗВИТКУ ДІТЕЙ 3 ПОРУШЕННЯМИ МОВЛЕННЯ В ІГРОВІЙ ДІЯЛЬНОСТІ
}

\author{
Бистранівська О. С. \\ викладач-методист \\ Комунальний заклад «Уманський гуманітарно-педагогічний фаховий \\ коледж імені Т. Г. Шевченка Черкаської обласної ради» \\ м. Умань, Украӥна
}

Гра є надзвичайно важливою основою для розвитку дітей будь якого віку, але особливо - дошкільного, для якого вона є провідним видом діяльності. Проте ігрова діяльність вимагає від дитини певного рівня розвитку мовлення та комунікативних навичок, які у дітей 3 порушеннями мовлення недостатньо розвинуті, що відповідно відображається на поведінці дитини у процесі гри.

Як свідчить аналіз науково-теоретичних джерел, питання розвитку мовлення дітей дошкільного віку у грі дослідники розглядали з різних точок зору: з психологічної (Ж. Піаже, Л.С. Виготський, О.Р. Лурія, Д.Б. Ельконін, Т.О. Піроженко, С.Л. Рубінштейн та ін.) та педагогічної (В.О. Сухомлинський, Ш.О. Амонашвілі, А.М. Богуш, Н.В. Гавриш, В.Г. Захарченко, С.І. Тихеєва, О.С. Ушакова та ін.).

В. Сухомлинський вважав, що гра - це величезне світле вікно, крізь яке в духовний світ дитини вливається живлющий потік уявлень, понять про навколишній світ, що гра $є$ іскрою, що засвічує вогник допитливості.

Л.С. Виготський зауважував, що гра є елементом розвитку і дитина, яка грається, створює собі уявну ситуацію замість реальної і діє в ній, звільняючись від ситуаційної прихильності і виконує певну роль згідно 3 тим переносним значенням, які вона додає навколишнім предметам.

На думку С. Л. Рубінштейна гра - це основний вид діяльності дитини, який зберігає і розвиває дитяче в дітях, гра їхня школа життя i практика розвитку.

Але всі дослідники зазначали, що гра $є$ найбільш вільною та невимушеною діяльністю, яка базується на бажанні дитини і приносить їй максимальне задоволення. У процесі гри дитина отримує великі можливості для самовираження, дослідження власних почуттів i переживань. Саме в процесі гри, як провідної діяльності, виникають основні психічні новоутворення у дітей дошкільного віку. 
Розвиток гри відбувається не спонтанно, а залежить від умов виховання дитини. Отже гра є оптимальним засобом для вирішення як розвивальних, так і корекційних завдань.

Мета статті - теоретично-методичне обгрунтування особливостей розвитку ігрової діяльності дітей дошкільного віку з порушеннями мовлення.

Зазначена проблема знайшла теоретичне обгрунтування в публікаціях вітчизняних науковців (М.К. Шеремет, В.О. Кондратенко, С.Ю. Конопляста, І.С. Марченко), присвячених ігровій діяльності дітей дошкільного віку з порушеннями мовлення. Вчені зазначають, що ігрова діяльність дітей 3 мовленнєвими порушеннями відстає у розвитку.

Діти дошкільного віку 3 тяжкими порушеннями мовлення найчастіше граються самі, а рівень їх взаємодії з ровесниками у грі дуже низький, як у дітей 3 нормальним розвитком 2-4 року життя (Р.О. Іванкова, В.О. Кондратенко, І.Б. Теплицька). В іграх найчастіше спостерігається ситуаційне маніпулювання іграшками і предметами, а у самостійній грі дитина $з$ порушеннями мовлення майже не застосовує предметів в ігровому розумінні (О.Н. Усанова).

Однак, при наявності великої кількості наукових робіт присвячених проблемам ігрової діяльності дітей з порушеннями мовлення причини виникнення іiі порушень, спеціальні умови ефективного формування ігрової діяльності дітей не знайшли свого вирішення.

Порушення мовленнєвого розвитку негативно впливають на формування особистості дитини, що позначається на процесах іiі соціальної адаптації.

Дітям 3 мовленнєвими порушеннями властиві: тривожність. Вони емоційно вразливі, бояться спілкуватися; замкнутість. Діти відсторонені від однолітків і дорослих внаслідок нерозуміння оточуючими їхнього мовлення невпевненість у власних силах. Діти переживають свою неспроможність зрозуміти повноцінно інструкцію та впоратися 3 певним завданням внаслідок заниженої самооцінки; негативізм, який проявляється неврівноваженістю, дратівливістю, впертістю; дитячі страхи, які виникають через травмуючі психіку дитини ситуації. В деяких випадках сильні або тривалі переживання переходять у невроз страху.

Тому в процесі організації корекційної роботи 3 дітьми 3 порушеннями мовлення слід враховувати не тільки особливості проявів мовленнєвого порушення, а й вторинні відхилення в розвитку дитини зумовлені даною патологією мовлення.

У дітей 3 порушеннями мовленнєвого розвитку спостерігаються труднощі деяких вищих коркових функцій (слухомовленнєвого сприй- 
няття, орієнтування в просторі тощо) та особливості протікання мовленнєвої діяльності (підвищена виснажливість, нерівномірна працездатність, порушення мовленнєвої пам'яті, схильність до пасивності). Внаслідок цього даній категорії дітей важко включитися в організовану педагогом ігрову діяльність. В процесі гри діти пасивні та не виявляють бажання активно діяти 3 предметами та іграшками. Порушення загальної і мовленнєвої моторики призводить до швидкої втомлюваності у процесі ігрової діяльності.

Для дітей дошкільного віку з порушеннями мовленнєвого розвитку, ігрова діяльність зберігає своє значення і є необхідною умовою всебічного розвитку їх особистості та інтелекту. Однак недоліки вимови звуків, обмеженість словникового запасу, порушення граматичної будови мови, а також зміни темпу мовлення - все це впливає на ігрову діяльність дітей, породжує певні особливості поведінки в грі. Так, наприклад, діти зі складними порушеннями вимови звуків досить часто втрачають можливість спільної діяльності з однолітками в грі через незрозуміле мовлення, невміння висловити свою думку, страх показатися смішними, хоча правила і зміст гри дітям зрозумілі.

Слабкість умовно-рефлекторної діяльності, повільне утворення диференціацій, нестійкість пам'яті ускладнюють включення дітей 3 порушеннями мовленнєвого розвитку в колективні ігри. Порушення загальної і мовленнєвої моторики, особливо у дітей 3 дизартрією, викликає швидку втомлюваність дитини в грі.

У дітей з порушеннями мовлення часто виникають труднощі при необхідності швидкого утворення нового динамічного стереотипу, тому в іграх діти не можуть відразу переключитися з одного виду діяльності на інший.

Діти зі зниженою збудливістю кори головного мозку, схильні до гальмівних реакцій, виявляють в грі боязкість, млявість, їх рухи скуті, вони швидко втомлюються. Дітям з підвищеною збудливістю не вистачає зосередженості, уваги і наполегливості у доведенні гри до кінця. Неврівноваженість, руховий неспокій, метушливість у поведінці, мовленнєва стомлюваність ускладнюють включення в колективну гру.

Гра посідає істотне місце в логопедичній роботі. Але, звичайно, було б не правильно здійснювати всю корекційну роботу лише ігровими методами. Логопед, враховуючи конкретні умови роботи 3 тими чи іншими дітьми, зокрема рівень їх розвитку, ставлення до занять, стомлюваність тощо, вирішує, коли і як використовувати ігри. Навчаючи дітей у процесі гри, педагог прагне, щоб радість від ігрової діяльності перейшла у радість навчання. Включаючи гру в заняття логопед турбується, щоб основне дидактичне завдання, яке складає зміст гри, відповідало навчальній меті заняття, було для дітей 290 
посильним, сприяло максимальній активізації не тільки мовлення а й розумової діяльності.

Взаємодія педагога 3 дитиною, $є$ незамінною основою, на якій найбільш природно та ефективно реалізуються корекційні завдання. Ігрова діяльність дітей з порушеннями мовлення формується тільки при безпосередньому впливі та керівництві педагога.

В організації та управлінні ігровою діяльністю педагог має зважати, що мовленнєва гра повинна приносити радість. Не слід примушувати дитину грати, потрібно створити умови для виникнення інтересу, проявів пізнавальної і творчої активності. Хвалити дитину навіть за найменші успіхи, особливо якщо щось вийшло у неї вперше. Спостерігати, аналізувати активність дітей в оволодінні мовленням, 3 тим, щоб допомогти їм засвоїти нові мовленнєві вміння і навички. Будувати свої взаємовідносини 3 дітьми на взаємній довірі, щиро розділяти їх радість, успіхи, показувати зразки правильного мовлення. Тобто гра $\epsilon$ ще засобом для створення позитивної атмосфери, взаєморозуміння та доброзичливості між педагогом і дітьми 3 порушеннями мовлення.

В основі ігрової діяльності лежить впевненість в тому, що кожна дитина має право бути такою, якою вона $\epsilon$, і у кожної дитини досить потенційних сил для того, щоб розвиватися і бути щасливою.

Дана стаття не вичерпує всіх аспектів порушеної проблеми. Багато питань методики формування і розвитку ігрової діяльності в процесі корекційної допомоги дітям 3 порушеннями мовлення не знайшли ще свого вирішення. Перспективи подальших досліджень вбачаємо у розробленні ефективних умов використання в корекційній роботі різних видів ігор для формування мовлення та комунікативної компетентності у дітей дошкільного віку з порушеннями мовлення.

\section{Література:}

1. Бурова А. П. Організація ігрової діяльності дітей дошкільного віку. 2-е вид. зі змін. та доп. Тернопіль, 2013. 296 с.

2. Піроженко Т. О. Особистість дошкільника - перспективи розвитку: навчально-методичний посібник. Тернопіль, 2010. 136 с.

3. Соботович Є.Ф. Концепція стандарту спеціальної освіти дітей дошкільного віку з порушеннями мовленнєвого розвитку. Дефектологія. 2002. № 1. С. 2-7.

4. Сухомлинський В.О. Серце віддаю дітям. Вибрані твори: В 5 т. Т. 3. Київ, 1977. С. 95-98; С. 176-185. 